whom I first met him back in the early 1960s while doing my own postdoctoral fellowship in psychiatric genetics in London. Later my partner James Shields had the brilliant idea of inviting Essen-Möller (as well as Slater) to blindly diagnose our Maudsley twins using the orientation they each had preferred while conducting their own twin studies of schizophrenia before World War II. Thus began a long and warm (and sometimes feisty) friendship over 30 years of meetings at each other's homes, international meetings, and in detailed scientific correspondence. Erik went out of his way to be helpful and to instruct and influence in a firm but gentle manner. In his contribution to Slater's Festschrift (Gaskell, 1979) he shows his mastery over many complex issues within behavioural genetics that have yet to be resolved. He preferred some kind of a mixed-model to explain the transmission of schizophrenia and could come up with many reasons to be sceptical about multifactorial polygenic models. He can also be considered to be the father of the multiaxial system that has come to dominate psychiatric nosology, and he was one of the first to embarrass notions about "schizophrenogenic" mothering with strong empirical counterarguments.

Erik Essen-Möller led an exemplary life as teacher, researcher, clinician, and friend-we shall all miss him very much.

Dr Essen-Möller was elected FRC Psych(Hon) in 1967.

IRVING I. GOTTESMAN

\section{Robert Kellner, formerly Professor, Department of Psychiatry, University of New Mexico, Albuquerque, New Mexico}

Dr Robert Kellner, Vice-Chairman and Professor of the Department of Psychiatry at the University of New Mexico at Albuquerque, died on 15 November 1992, aged 70. He was particularly known for his work on hypochondriasis including his single-author volume, Somatization and Hypochondriasis (1986). He was a modest man and a very private person. He made light of his wartime experiences. Imprisoned twice before he was 17, he escaped from Czechoslovakia in 1939 , made his way to Greece and from there to North Africa, where he joined the British army and was decorated after the siege of Tobruk. He then came to Britain and flew as a rear gunner in a Czech bomber squadron stationed in Tain, Scotland. An accomplished photographer, he later published a fine book of wartime photographs. A committed social democrat, he returned to Czechoslovakia until 1948 when he was, once more, forced to escape his homeland. After receiving the Anatomy Prize at Charles University, he attended medical school at Liverpool University and graduated $\mathrm{MB}, \mathrm{ChB}$, in 1955 . He went into general practice in Chester and was an excellent family doctor. He managed to find time during this period to write a book on psychiatry in general practice (Family Ill Health, an investigation in general practice (1963). This was published by Tavistock Press and was the beginning of a thesis for his MD, PhD degrees, also obtained at Liverpool University.

Soon after, he took up psychiatry as a specialty and later decided to move because of his health. By this time, he had married his wife, Diana (MB, Liverpool, 1954), and they decided to emigrate to the United States. They settled in Albuquerque, where he thought the people and the system were sympathetic to the less fortunate in society. He never lost his concern for his fellow man. He was passionately against the death penalty and was intolerant of man's inhumanity to man wherever it took place. Unlike many who had been oppressed, he was never bitter and struggled on in his own way. He was a devoted and active member of Amnesty International and contributed both by his writings and donations. A keen chess player, he delighted in playing without a board and memorising the moves with his opponents. He was known to read a newspaper with his back to the board while instructing his opponent what his next move was. Bob had a marvellous sense of humour, frequently dry and occasionally unnoticed. He was one of a few people whose own laughter improved the telling of a story.

He was an excellent teacher (the Kellner Teaching Award honouring him was established in 1986), scientist, photographer, painter, chess player, raconteur, colleague, friend, father, and husband. In addition, a memorial symposium will be held annually in his honour. Bob is survived by his wife, Diana, and two sons, Thomas, physician, and Arthur, a neuropsychologist.

George M. SimpSON

\section{Erratum}

In the obituary for $\mathrm{Dr}$ Giuseppe Pampiglione (Psychiatric Bulletin, July 1993, 17, 443), Dr Pampiglione was wrongly described as being consultant psychiatrist at the Royal Free and at Charing Cross Hospital. Dr Pampiglione was in fact consultant neurophysiologist.

\section{The deaths of the following have also been reported:}

Daud Mahomed Bassa, formerly Consultant Psychiatrist; 64 Sandringham Avenue, Merton Park, London.

Alan Mervyn Edwards, 10 Sherrards Park Road, Welwyn Garden City, Herts AL8 7JP.

Henry Douglas Lamb, retired; 4449, Apartment 107, Meandering Way, Tallahassee, Florida 32308, USA.

Goal Megh Ras, Consultant Psychiatrist, Psychiatric Clinic, Punjabi Bagh, Patiala-147001, India. 